\title{
JOINT DEVELOPMENT AGREEMENT SEBAGAI SOLUSI PENYELESAIAN SENGKETA WILAYAH ZONA EKONOMI EKSKLUSIF LAUT NATUNA ${ }^{1}$
}

\author{
Djarot Dimas Achmad Andaru
}

Fakultas Hukum, Universitas Indonesia

Jl. Prof. Mr. Djokosoetono, Pondok Cina, Kecamatan Beji, Kota Depok, Jawa Barat, 16424

djarot.dimas@gmail.com

\begin{abstract}
The dispute over the waters of the exclusive economic zone of the Natuna Sea between Indonesia and China is part of the dispute over the claim of the Natuna Sea area. China claims the North Natuna Sea on the basis of its nine-dash line policy. Natuna waters are predicted to store hydrocarbon natural resources with a capacity of 11 billion barrels. A legal solution that can be a solution in this area is through the creation of a Joint Development Agreement or JDA. In order to be implemented effectively, Indonesia needs to pay attention to several aspects such as political will, domestic stigma and state understanding regarding the design of the JDA. With the juridical-normative method towards international regulations as well as international policies and legislation. This article will provide recommendations to Indonesia that the utilization of Natuna Sea resources can be carried out through the JDA with China even though it is in a dispute status with due regard to maintaining the status quo.
\end{abstract}

Keywords: Joint Development Agreement; Hydrocarbon; Exclusive Economic Zone

\begin{abstract}
Abstrak
Permasalahan sengketa pada perairan zona ekonomi eksklusif Laut Natuna antara Indonesia dan China merupakan bagian dari sengketa klaim wilayah Laut Natuna. China mengklaim Laut Natuna Utara atas dasar kebijakan nine-dash line. Perairan Natuna diprediksi menyimpan sumber daya alam hidrokarbon dengan kapasitas 11 billion barrel. Solusi hukum yang dapat menjadi solusi di wilayah tersebut adalah melalui pembuatan kerjasama pengembangan (joint development agreement) atau JDA. Agar terlaksana secara efektif Indonesia perlu memperhatikan beberapa aspek seperti political will, stigma domestik dan pemahaman negara terkait perancangan JDA. Dengan metode yuridis-normatif, komparatif terhadap peraturan internasional maupun kebijakan internasional beserta perundang-undangan. Artikel ini akan memberikan rekomendasi kepada Indonesia bahwa pemanfaatan sumber daya Laut Natuna dapat dilaksanakan melalui JDA dengan China walaupun berada dalam status sengketa dengan memperhatikan tetap mempertahankan status quo.
\end{abstract}

Kata Kunci: Joint Development Agreement; Sengketa Wilayah; Zona Ekonomi Eksklusif

\footnotetext{
${ }^{1}$ Artikel ini merupakan hasil penelitian mandiri penulis pada Program Magister Hukum Universitas Indonesia yang dilaksanakan pada bulan Januari 2019 - Juni 2020.
} 


\section{A. Pendahuluan}

Joint Development Agreement, merupakan suatu konsep perjanjian internasional antara dua subjek negara. Perjanjian tersebut memuat skema pembagian dan penggunaan sumber daya (resource sharing) yang disusun untuk mewujudkan suatu tujuan bersama. Konsep Joint Development Agreement atau disebut dengan istilah JDA, dapat menjadi solusi penengah terhadap sengketa wilayah perairan Laut Natuna Utara, yang terjadi antara Indonesia dan China (David M. Ong, 1999). Konsep JDA pertama kali dikenal dan dikembangkan dalam aspek perjanjian bisnis properti. Ketika seorang pemilih tanah landlord bekerjasama dengan pengusaha developer properti yang memiliki modal dan keahlian untuk membangun rumah. Seorang tuan tanah tersebut akan menyediakan atau memasukkan tanahnya kepada pengembang untuk dikelola sebagai sumber daya. Sedangkan pengembang kemudian menggunakan tanah tersebut tanpa membelinya dengan tujuan untuk melakukan pembangunan perumahan sesuai dengan spesialisasi dan keahlian yang dimilikinya. Karena sumber daya pembagunan tersebut berasal dari dua pihak yang masing-masing melakukan inbreng maka keuntungan yang dihasilkan dari penjualan rumah tersebut kemudian dibagi antara penyedia lahan dan pengembang rumah.

Hingga tahun 1989 beberapa negara di dunia telah mencoba menerapkan Joint Development Agreement dalam rangka kerjasama pengelolaan sumber daya lepas pantai. Salah satunya yaitu Malaysia dan Thailand yang membuat Memorandum of Understanding mengenai pencanangan joint development agreement terhadap pemanfaatan bersama zona Teluk Thailand (Alexander \& Charney, 2014). Walaupun pada akhirnya upaya tersebut menemui kegagalan akibat para pihak sulit untuk mencapai konsensus terhadap definisi delimitasi atau batasan wilayah yang disengketakan oleh Para pihak. (Masahiro Miyoshi, 1999). Ide mengenai penggunaan mekanisme JDA dalam menegelola wilayah sengketa pertama kali digagas oleh William Onorato pada tahun 1968. Onorato menempatkan JDA sebagai metode alternatif penyelesaian sengketa pemanfaatan sumber daya alam di wilayah klaim negara yang saling tumpang tindih/overlap (Onorato, 1981). JDA dipandang sebagai suatu pendekatan yang dapat menjadi alternatif penyelesaian sengketa Laut Natuna bagian Utara, namun hingga saat ini penggunaan metode Joint Development Agreement sebagai alternatif penyelesaian konflik masih menuai diskusi Panjang mengenai efektifitas penggunaan metode tersebut sebagai solusi.

Praktik Joint Development Agreement ini kemudian diadopsi dan ditransplantasi ke dalam lingkup perjanjian antar negara. Ide penggunaan mekanisme Joint Development Agreement dalam pemanfaatan hidrokarbon lepas pantai dalam lingkup internasional pertama kali digagas oleh Hakim International Court of Justice (ICJ) Philip C Jessup sebagai suatu pendekatan keadilan dan kesetaraan bilateral dalam penyelesaian suatu sengketa wilayah Internasional. Pada kasus North Sea Continental Shelf antara Jerman melawan Denmark. Pada saat itu putusan terpisah separate opinion Hakim Jessup mendiskusikan mengenai topik kemungkinan dibentuknya suatu rezim wilayah yuridiksi gabungan pada zona yang saling bersinggungan bagi kedua negara untuk saling dapat melakukan pemanfaatan dan eksploitasi sumber daya alam (International Court of Justice, 1969).

Dalam praktiknya penerapan JDA justru menuai banyak kegagalan dalam mendiversifikasi konflik. Song Xue, Associate Professor institute of international studies, Universitas Fudan, Shanghai mencoba menjawab pertanyaan tersebut dalam papernya yang berjudul Why Joint Development Fail: Implications for the South China Sea. Mengemukakan bahwa penyebab utama upaya kebijakan joint development agency di Laut China Selatan gagal, karena disebabkan suatu sebab yang cukup sederhana yaitu dalam kondisi konflik, hubungan bilateral antara China dan 
negara yang berkonflik tidak harmonis sehingga menimbulkan kesulitan dalam komunikasi dan negosiasi yang dibutuhkan untuk menjalankan perjanjian secara efektif (XUE \& Assistant Professor in the Institute of International Studies Shanghai, n.d.).

Robert Beckman dan Leonardo Bernard anggota Center for International Law University of Singapore dalam proyek yang didanai pemerintah Singapura membuat Framework for The Joint Development of Hydrocarbon Resource. Di dalam kerangka tersebut Beckman dan Bernard mencoba untuk merumuskan beberapa kondisi yang berfungsi sebagai syarat dari terciptanya joint development agreement di bidang pemanfaatan hidrokarbon secara efektif. Syarat syarat tersebut antara lain adalah harus adanya pengakuan terhadap sengketa tumpang tindih wilayah oleh kedua negara, political will, opini politik nasional dan beberapa faktor lain (Beckman \& Schofield, 2014).

Dalam menyusun proyek karyanya, Beckman dan Bernard terinspirasi dan mempelajari karya Masahiro Miyoshi seorang Profesor Hukum Internasional University of Durham Inggris, untuk kemudian mencoba menarik kesimpulan dan mempelajari mengapa joint development agreement cenderung gagal. Mashiro Miyoshi dalam karyanya berjudul The Joint Development of Offshore Oil and Gas in Relation to Maritime Boundary, mencoba menghubungkan dan mendeskripsikan mengenai hubungan bentuk wilayah atau geomorfologi kelautan dan implikasinya terhadap joint development agreement. Tulisan tersebut dipublikasikan oleh International Boundaries Research Unit, Departemen Geografi, University of Durham Inggris (Masahiro Miyoshi, 1999).

Guna menjawab pertanyaan seputar bagaimana penerapan Joint Development Agreement dapat memberikan dampak positif sekaligus menjadi solusi diversifikasi sengketa wilayah Laut Natuna, maka perlu disusun suatu acuan khusus mengenai halhal apa sajakah yang perlu diperhatikan dan dipersiapkan oleh Pemerintah Indonesia dalam merancang JDA. Penilaian aspek nasional dan pengadopsian nilai nilai bilateral menjadi faktor penting dalam menghasilkan suatu JDA secara efektif. Indikator dan faktor penentu keefektifan suatu JDA tidak dapat ditentukan secara umum. Masing-masing JDA memiliki keunikan tersendiri karena dipengaruhi oleh kepentingan, maksud, tujuan dan juga kebiasaan customary negara-negara yang mengikatkan diri pada kontrak JDA.

Artikel ini akan memberikan perspektif hukum mengenai unsur-unsur apa saja yang perlu diperhatikan oleh suatu negara secara umum dalam pembuatan JDA, selanjutnya secara khusus artikel ini akan membahas mengenai bagaimana JDA dapat menjadi suatu pilihan solusi dalam menangani sengketa yang terjadi antara Indonesia dan China. Pembahasan secara khusus diperlukan untuk mempertajam aspek nasional, hukum kebiasaan dan kondisi sebab-sebab yang dipersengketakan.

\section{B. Metode Penelitian}

Pendekatan kualitatif merupakan pendekatan yang digunakan dalam penelitian ini. Pendekatan kualitatif adalah suatu pendekatan penelitian yang menitikberatkan pada pengamatan atas suatu peristiwa, baik pengamatan secara langsung empiris atau pengamatan dalam suatu kondisi terkontrol. Pendekatan kualitatif menggunakan data dalam bentuk deskriptif yang disimpulkan dalam bentuk preskriptif melalui proses analisis data. Landasan teori dalam bentuk metode penelitian digunakan sebagai panduan dan acuan penelitian, Metode penelitian yang digunakan dalam penelitian ini adalah metode penelitian hukum atau yuridis normatif. Penelitian yuridis normatif menggunakan bahan sumber hukum berupa teks perundangundangan, yurisprudensi dan literatur yang berkaitan dengan permasalahan yang diteliti (Peoples, 2010).

Selain menggunakan metode normatif yuridis, metode perbandingan hukum juga digunakan dalam untuk membandingkan beberapa JDA yang pernah dilaksanakan di 
berbagai negara dalam mengeksplorasi, mengeksploitasi dan mengelola sumber daya alam pada wilayah sengketa. Comparative law, merupakan metode penyelidikan dengan tujuan untuk memperoleh pengetahuan yang lebih dalam tentang hukum tertentu (Sclessinger, 1959). Sumber hukum yang menjadi acuan dalam penelitian ini secara umum mengacu pada yurisprudensi dan juga literatur hukum yang memuat dan menjelaskan terkait Joint Development Agreement secara teoritis dan konseptual. Literatur teoritis dan konseptual serta yurisprudensi North Sea Continental Shelf Case Germany $v$ Denmark yang diputus oleh ICJ pada Tahun 1969. Dari hasil analisis dan diskusi tersebut kemudian akan ditarik suatu kesimpulan dalam bentuk preskriptif dalam saran normatif mengenai apa yang harus diperhatikan Indonesia dalam mempersiapkan dan membuat JDA atas pemanfaatan sumber daya hidrokarbon di wilayah laut yang masih dalam status sengketa, khususnya laut Natuna Utara.

\section{Hasil dan Pembahasan}

\section{Joint Develompent Agreement} menawarkan solusi bagi pengelolaan sumber daya alam Hidrokarbon di wilayah Laut Natuna. Walaupun perairan Laut Natuna dalam status sengketa klaim antara Indonesia yang mengakui wilayah tersebut sebagai bagian dari Zona Ekonomi Eksklusifnya dan China yang mengakui hak atas sumber daya alam area perairan tersebut atas dasar klaim sembilan garis putusputusnya. JDA menawarkan sebuah solusi bagi kedua negara untuk tetap dapat melakukan pengelolaan sumber daya alam di wilayah tersebut meskipun perairan yang bersangkutan berada dalam status sengketa.

JDA menawarkan keuntungan bagi kedua belah pihak terlepas dari sengketa yang ada, namun untuk menuju terciptanya JDA antara Indonesia dan China, terdapat beberapa syarat khusus bagi dua negara tersebut untuk dapat menyepakati sebuah JDA. Tantangan utama terletak pada political will kedua negara tersebut untuk mengakui adanya sengketa yang terjadi, serta kemauan untuk menjembatani permasalahan tersebut melalui adanya suatu solusi kerjasama dalam bidang pengelolaan sumber daya alam untuk kepentingan bersama.

Di sisi lain JDA memberikan peluang bagi kedua negara untuk dapat memperkuat hubungan bilateral dan kesadaran akan adanya wilayah sengketa tersebut, sehingga diharapkan JDA akan menghantarkan kedua negara yang bersengketa untuk dapat menghasilkan suatu kesepakatan damai (win win solution). Adapun kunci utama untuk menuju ke arah tujuan tersebut kedua negara wajib memperhatikan betul beberapa aspek berikut:

1. Sengketa Wilayah Zona Ekonomi Eksklusif dan Landas Kontinen

Lahirnya konsep perpanjangan yurisdiksi negara pada landas kontinen tersebut menyusul deklarasi Presiden Trumman yang berisi mengenai klaim Amerika Serikat terhadap area landas kontinen atau dasar laut yang menjadi satu kesatuan dengan wilayah daratan Amerika Serikat, terlepas bahwa landas kontinen tersebut berada di bawah laut bebas atau bersinggungan dengan wilayah negara lain. Deklarasi yang di deklarasikan pada 28 September 1946 tersebut merupakan hasil upaya Amerika Serikat yang berusaha menguasai sumber daya alam berupa sumber hidrokarbon yang terkandung di dalam landas kontinen (Lucky, 2015). Hasil dari deklarasi tersebut kemudian menciptakan suatu konsep hukum internasional berupa konsep zona ekonomi eksklusif dan perpanjangan landas kontinen yang diadopsi oleh Konvensi Hukum Laut PBB pada tahun 1982.

Sebagai respon terhadap tindakan Amerika Serikat, negara-negara lain di dunia kemudian turut berlomba-lomba untuk berusaha menguasai sumber daya alam hidrokarbon yang terdapat di dalam area landas kontinen lepas pantai mereka, tujuan utamanya adalah untuk kepentingan ekonomi dan keamanan sumber daya strategis negara berupa sumber energi yang 
berasal dari minyak dan gas. Namun munculnya konsep dan ketentuan mengenai hak perpanjangan landas kontinen bagi negara-negara pantai ternyata justru banyak menimbulkan sengketa. Keberadaan perpanjangan area landas kontinen sering kali bersinggungan hingga saling tumpang tindih dengan yurisdiksi zona ekonomi eksklusif milik negara lain (Lucky, 2015), dimana dalam zona ekonomi eksklusif negara pantai berhak untuk memiliki sumber daya yang berada di kolom air hingga di bawah dasar laut atau landas kontinen.

Satu dekade setelah munculnya klaim Amerika Serikat tersebut, meja lembaga arbitrase maupun mahkamah internasional mulai dipenuhi kasus-kasus sengketa klaim wilayah zona ekonomi eksklusif maupun zona landas kontinen. Kasus North Sea Continental Shelf antara Jerman melawan Denmark dan Belanda salah satunya. Kasus yang mempertanyakan mengenai Batasan zona landas kontinen ketiga negara tersebut, dimana Jerman menginginkan porsi wilayah yang lebih luas karena merasa dirugikan dengan bentuk wilayah pantai yang cekung pada Laut Utara (International Court of Justice, 1969).

\section{Penyelesaian Sengketa dan Prinsip Equidistance}

Dalam kasus sengketa North Sea Continental Shelf prinsip pembagian wilayah secara equidistance atau sama sama jauh melalui penarikan garis sama panjang dari garis pangkal ternyata tidak memberikan solusi terhadap permasalahan yang dihadapi. Pembagian hak wilayah berdasar prinsip equidistant tidak semudah membagi secara adil secara fisik yang disepakati oleh para pihak yang bersengketa (Jain, 2015).

Prinsip equidistant justru sering tidak mempertimbangkan pandangan personal yang dimiliki oleh negara terhadap konsep equal atau adil terhadap pembagian equidistant bagi mereka. Selain itu suatu kesepakatan yang kemudian benar-benar membawa rasa keadilan bagi setiap pihak merupakan suatu konsep yang cenderung utopis dan sulit untuk benar-benar terwujud tanpa adanya suatu kompromi salah satu pihak (Azaria, 2016). Oleh karena itu dalam memutus kasus North Sea Continental Shelf, Hakim Phillip C Jessup kemudian membuat Opini Terpisah terkait saran mengenai bagaimana seharusnya pembagian wilayah landas kontinen dilakukan di Laut Utara.

Hakim Phillip C Jessup, kemudian memberikan suatu konsep dalam opini terpisahnya, bahwa permasalahan sengketa landas kontinen yang memiliki latar belakang motif ekonomi dapat diselesaikan secara damai dan adil jika negara-negara yang menjadi para pihak di dalamnya membuat suatu kesepakatan pemanfaatan dan pengembangan bersama atau Joint Development sumber daya alam hidrokarbon yang terkandung pada landas kontinen laut utara. Dengan demikian kepentingan ekonomi masing-masing pihak yang menjadi alasan utama timbulnya sengketa dapat terpenuhi (Anderson, 2015).

\section{Joint Development Agreement sebagai} Solusi Alternatif Penyelesaian Sengketa

Pertanyaan umum yang kemudian muncul ketika JDA diajukan sebagai solusi alternatif penyelesaian sengketa adalah terkait bagaimana fungsi dan peranan JDA dalam penyelesaian sengketa. Secara umum perlu dipahami bersama bahwa secara umum JDA bukan sebuah alat penyelesaian sengketa utama seperti halnya upaya arbitrase atau pengadilan internasional. Dalam hal ini JDA hanya berperan sebagai suatu moda yang dapat digunakan untuk mempercepat atau menuju kepada penyelesaian sengketa melalui jalur kerjasama pengelolaan sumber daya alam.

Penggunaan JDA sebagai solusi pemecahan sengketa muncul sebagai respon dari timbulnya sengketa tumpang-tindih wilayah lepas pantai, terutama setelah munculnya ketentuan hukum internasional mengenai penambahan landas kontinen berdasarkan Artikel 76 UNCLOS yang menyatakan bahwa negara pantai berhak untuk memperpanjang garis batas landas kontinennya hingga 350 mil laut dari garis 
pangkal melalui pemberitahuan kepada Commission on the Limits of the Continental Shelf, yang kemudian akan memberikan rekomendasi mengenai garis batas luar perpanjangan landas kontinen tersebut (United Nations General Assembly, 1994).

Dalam hal ini perlu dipahami bahwa konsep JDA sebagai alternatif solusi penyelesaian sengketa, bukan berarti JDA dapat menyelesaikan sengketa secara langsung. Ketika JDA disepakati di atas wilayah yang disengketakan, status quo wilayah yang dipersengketakan tersebut akan tetap ada dan melekat, hanya saja secara prakteknya JDA memberi jembatan bagi para pihak untuk tetap dapat memperoleh keuntungan secara ekonomis melalui adanya kerjasama eksplorasi dan eksploitasi sumber daya alam yang terdapat di dalam wilayah tersebut (Desbarats, Todesco, \& Royer, 2016).

\section{Latar Belakang Sengketa Wilayah Zona Ekonomi Eksklusif Laut Natuna}

Sengketa yang terjadi antara Indonesia dan China di wilayah Laut Natuna merupakan imbas dari deklarasi China yang mengakui secara sepihak penambahan wilayah laut melalui kebijakan sembilan garisnya (nine dash line policy) yang kembali dipertegas di tahun 2013. Klaim sepihak Republik Rakyat China (RRC) tersebut pertama kali dipublikasikan oleh Republic China (Taiwan) pada 1 November 1947 sebelum terjadi pengambilalihan oleh partai Komunis China yang mendirikan RRC di tahun 1949. Klaim Republik China (ROC) (Wang, 2010) pada masa itu meliputi 11 garis putus-putus yang dideskripsikan sebagai kepulauan China Selatan, namun kemudian setelah pengambilalihan ROC oleh RRC, Klaim 11 garis putus-putus tersebut diambil alih oleh pemerintahan RRC. Perdana Menteri RRC Zhou Enlai kemudian merevisi klaim tersebut menjadi sembilan garis putus-putus setelah mengurangi dua garis pada Teluk Tonkin yang dikuasai oleh Republik Vietnam Utara yang pada kala itu sebagai tergabung di dalam mitra komunis PRC.
Namun tidak hanya PRC yang mengakui mengenai klaim nine dash line, hingga tahun 1999 ROC perdana menteri Lee Teng Hui melalui Menteri luar negerinya mengeluarkan klaim bahwa seluruh pulau yang ada di kepulauan Spratly dan Parcel secara historis, geografis dan hukum merupakan bagian dari wilayah kedaulatan ROC. Namun klaim ROC tersebut tidak diikuti oleh suatu aksi konkrit dalam menunjukkan kedaulatan pada wilayah tersebut.

Aksi konkrit terhadap klaim wilayah Laut China Selatan baru dilakukan pertama kali oleh PRC pada 7 Mei 2009, pada saat itu PRC menyerahkan peta wilayah kepada PBB termasuk 9 garis putus-putus di wilayah Laut Cina Selatan yang menandai sebagai wilayah yang mereka klaim. Aksi tersebut kemudian menuai protes diplomatik dari negara Vietnam, Malaysia, Filipina dan Brunei Darussalam (MORTON, 2016).

Walaupun secara langsung wilayah Laut Natuna Indonesia pada masa itu belum masuk dalam wilayah yang diklaim oleh China, Pemerintah Indonesia di bawah administrasi Presiden Susilo Bambang Yudhoyono telah menyampaikan protes diplomatik melalui surat yang disampaikan kepada komisi delimitasi dan landas kontinental, surat tersebut berisi pernyataan bahwa klaim China terhadap sembilan garis putus-putus di wilayah Laut China Selatan tidak memiliki dasar hukum internasional. Empat tahun kemudian protes diplomatik tersebut ternyata tidak menghentikan langkah negeri tirai bambu tersebut untuk memulai okupasi militer di daerah Laut China Selatan, khususnya kepulauan Spratly, tidak hanya itu, klaim Sembilan garis putus-putus juga ikut diperluas menjadi sepuluh garis putus-putus yang kini bersinggungan dengan wilayah Zona Ekonomi Eksklusif Laut Natuna milik Indonesia.

Di sisi lain Indonesia di bawah administrasi Presiden Jokowi dengan nawacita Poros Maritimnya, sedang menyusun program intensifikasi pengurangan dan penindakan illegal, 
unregulated dan unreported fishing, (selanjutnya disebut IUU Fishing). Salah satu area yang menjadi wilayah kontrol penguatan hukum anti IUU Fishing adalah wilayah Laut Natuna, wilayah zona ekonomi eksklusif tersebut merupakan wilayah yang paling sering dilanggar oleh kapal-kapal ikan asing yang melakukan pengambilan ikan secara ilegal, di antaranya termasuk kapal penangkap ikan milik China.

Pemerintah Indonesia mengambil sikap protektif dan defensif terhadap keberlangsungan kepentingan nasional pada wilayah zona ekonomi eksklusif Laut Natuna Utara. Sikap kebijakan stances Indonesia ini menunjukan political will pemerintah untuk menguasai dan mempertahankan kekuasaan secara mutlak pada wilayah ZEE yang bersinggungan tersebut. Sikap Indonesia tersebut tidak sejalan dan cenderung bertabrakan dengan sikap political will China yang mengakuisisi area di dalam sepuluh garis putus-putusnya sebagai zona perairan historis milik China. Oleh karena itu China berhak memanfaatkan wilayah tersebut, tidak hanya sebagai wilayah penangkapan ikan namun sebagai wilayah eksplorasi dan eksploitasi hidrokarbon (Supriyanto, 2016).

5. Hal-hal yang perlu diperhatikan dalam Penerapan Joint Development Agreement

Sejarah mencatat bahwa sejak pertama kali konsep Joint Development Agreement atau JDA digagas oleh William Onorato, yang kemudian menjadi inspirasi dan diadopsi oleh Hakim Phillip $C$ Jessup sebagai saran penyelesaian sengketa. Reputasi dan perjalanan konsep JDA tidak selalu menuai suatu catatan sukses. Seringkali penerapan JDA pada wilayah sengketa justru gagal dalam prosesnya karena disebabkan oleh berbagai macam faktor.

Kegagalan dalam penerapan JDA sebagai solusi yang menjadi jembatan sengketa antar negara itu sendiri pernah dialami oleh Indonesia tatkala membuat JDA dengan Australia terhadap wilayah yang disebut Timor Gap, yaitu letak persinggungan antara Zona Ekonomi Eksklusif Indonesia dengan zona perpanjangan landas kontinen yang diklaim oleh Australia. Perjanjian eksplorasi bersama antara Indonesia dan Australia yang ditandatangani pada 11 Desember 1989 dan mulai berlaku pada 9 Februari 1991 kemudian berakhir setelah Timor Timur merdeka di tahun 2002. Oleh karena itu secara prinsip rebus sic stantibus perjanjian Timor Gap antara Australia dan Indonesia otomatis tidak berlaku (Sforza, 1999).

Di negara ASEAN lain yaitu Malaysia dan Thailand juga pernah menerapkan JDA terhadap wilayah sengketa landas kontinen antara dua negara tersebut yang terletak di wilayah Teluk Thailand. MoU mengenai pengadaan JDA telah ditandatangani kedua belah pihak pada tahun 1979 namun 15 tahun kemudian di tahun 1994 perjanjian JDA baru benar-benar terlaksana dikarenakan sulitnya mencapai kesepakatan dalam pembagian wilayah pengembangan serta eksplorasi yang cukup luas (D M Ong, 1999).

Upaya negara-negara di dunia dalam menerapkan JDA di wilayah sengketa menjadi suatu tantangan tersendiri karena menyangkut aspek permasalahan yang luas dari mulai faktor perbedaan tujuan politik atau political will, stigma masing-masing pihak, hingga perbedaan tingkat ekonomi dan penguasaan teknologi yang kemudian menjadi akar dari munculnya rasa tidak saling percaya antara para pihak.

Masahiro Miyoshi dalam artikelnya berjudul Joint Development of Offshore Oil and Gas in Relation to Maritime Boundary Delimitation menyoroti permasalahan umum mengapa JDA cenderung gagal, melalui proses studi dan penelitian beberapa penerapan JDA, Miyoshi mengemukakan bahwa penyebab utama dari gagalnya JDA adalah kurangnya awareness mengenai kondisi atau kepentingan masing masing pihak yang bersengketa. Dimana awareness tersebut akan berperan menjadi kunci kompromi antara para pihak yang dapat dituangkan ke dalam sebuah perjanjian JDA. 
Penelitian Miyoshi tersebut kemudian diteruskan oleh Robert Beckman dan Leonardo Berard yang menulis hasil temuannya terkait mengapa JDA cenderung gagal pada artikel berjudul Framework for The Joint Development of Hydrocarbon Resource yang diterbitkan pada tahun 2010. Dalam artikel tersebut Beckman dan Bernard mengemukakan mengenai empat faktor utama penghambat JDA yaitu minimnya pengakuan para pihak yang bersengketa terhadap sengketa yang terjadi, kurangnya keselarasan Political Will para pihak, faktor stigma sosial dan politik serta faktor lain yang meliputi faktor tingkat ekonomi dan penguasaan teknologi.

Wacana JDA sebagai solusi tumpang tindih klaim multi negara terhadap wilayah laut China Selatan kemudian muncul sebagai bentuk respon terhadap permasalahan sengketa klaim China terhadap Laut China Selatan yang menuai protes internasional pada tahun 2013. Mengenai hal tersebut pada tahun 2019 Song Xue dari Institute of International Studies, Universitas Fudan Shanghai, kemudian menulis pendapatnya dalam sebuah artikel berjudul Why Joint Development Fail: Implications for the South China Sea. Di dalam artikelnya Xue berpendapat bahwa kerjasama JDA dengan China sulit terjadi terlepas sambutan dari pemerintah China, hal tersebut dikarenakan adanya faktor stigma negatif yang kuat negara-negara pantai Laut China Selatan terhadap China serta tidak adanya awareness atau pengertian terhadap pengakuan klaim nine dash line China di Laut China Selatan.

\section{Konsep Penerapan Joint Development Agreement di Laut Natuna Utara}

Sekilas mekanisme Joint Development Agreement menawarkan solusi konkrit, sederhana dan efektif yang langsung menyasar kepada inti permasalahan, namun tanpa disadari bahwa secara normatif konsep Joint Development Agreement didesain sepenuhnya untuk pemenuhan kepentingan dan tujuan bisnis secara murni. Joint
Development Agreement memiliki prinsip equitable sharing, yang nilai manfaatnya dihitung secara murni menggunakan ukuran ekonomi. Sedangkan negara sebagai subjek hukum dalam melakukan okupasi dalam rangka kebijakan ekspansi negara tidak hanya memiliki motif tujuan ekonomi, melainkan juga mencakup kepentingan politik, sosial dan pertahanan negara.

Perlu dipahami juga, walaupun dapat menggunakan faktor-faktor tersebut sebagai acuan pokok tiap-tiap sengketa memiliki iklim dan sifat keunikannya masing-masing yang perlu diperhatikan serta diperhitungkan untuk menjadi poin yang perlu diperhatikan para pihak jika ingin melakukan JDA. Faktor-faktor yang mendasari kesuksesan suatu JDA tidak dapat disamaratakan dengan mudah dan menganggap bahwa faktor tersebut akan berpengaruh pada setiap JDA terhadap wilayah perairan yang dipersengketakan.

Dalam konsep penerapan JDA di Laut Natuna Utara antara pemerintah Indonesia dan China, kemudian perlu diperhatikan beberapa faktor berupa latar belakang sengketa, maksud dari para pihak, tujuan politik tiap tiap negara, serta stigma masyarakat terhadap pemerintah China. Dengan melihat kondisi latar belakang dan kondisi sengketa yang terjadi antara Indonesia dan China, Indonesia masih menerapkan kebijakan tegas terhadap persinggungan klaim ZEE Nasional dan nine dash line China di Laut Natuna Utara, dengan demikian komunikasi antara Jakarta dan Beijing untuk membahas upaya mediasi atau kemungkinan penyelesaian konflik lainnya termasuk opsi kerjasama JDA cukup sulit untuk terjadi.

Selain itu kebijakan nasional Indonesia yang sedang mengarah kepada wacana perwujudan poros maritim dunia kemudian menyebabkan Indonesia menerapkan kebijakan ketat yang berfokus kepada mengembangkan kejayaan maritim baik dalam segi ekonomi maritim melalui pemberantasan illegal, unreported and unregulated fishing dan pengoptimalan pemanfaatan sumber daya laut, serta dalam 
segi pertahanan dalam bentuk penegakan hukum anti penyelundupan orang perbudakan, pembajakan dan pencurian sumber daya laut, yang akan diwujudkan melalui peningkatan armada keamanan laut sesuai Minimum Essential Force.

Sedangkan di sisi lain pemerintah China sedang gencar-gencarnya untuk membuktikan penguasaan terhadap klaim nine dash line mereka melalui pengerahan kekuatan armada perikanan yang menjangkau hingga Laut Natuna dan aktivitas militer di sekitar gugus kepulauan Spratly dan Mischief di Laut China Selatan. Walaupun pemerintah China hadir di Laut China Selatan dengan tangan terbuka untuk menjalin kerjasama dengan negara-negara lain dalam hal keamanan dan pemanfaatan sumber daya alam. Namun justru kebijakan tersebut dipandang sebagai cara China untuk memperoleh pengakuan hukum terhadap klaim nine dash line oleh komunitas global. Secara konsep, JDA antara Indonesia dan pemerintah China pada zona wilayah sengketa Laut Natuna bagian utara dapat dilakukan jika kedua belah pihak dengan memperhatikan dan berusaha untuk menyelesaikan permasalahan yang ada.

\section{Political Will}

Perbedaan Political Will akan menjadi penghambat berjalanya joint development agreement antar negara, terlebih jika perbedaan political will dipandang terlalu ekstrim, seperti yang terjadi antara Indonesia dan China maka faktor tersebut akan menghambat lebih jauh hingga masuk ke dalam faktor pengakuan sengketa antara para pihak. Dalam skenario tersebut maka salah satu pihak wajib untuk membuka jalur diplomasi dan pembicaraan bilateral guna mengkompromikan serta mempertemukan political will kedua belah pihak sehingga dapat tercapai suatu common sense berupa adanya kepentingan bersama dan munculnya semangat kerjasama antar kedua belah pihak.

Selain itu latar belakang terjadinya sengketa turut menyumbang informasi penting yang tidak hanya wajib diketahui namun harus dipahami secara mendalam oleh kedua belah pihak yang bersengketa. Pemahaman mengenai tuntutan klaim, kepentingan dan pandangan para pihak menjadi faktor penentu dalam perumusan norma-norma kerjasama pemanfaatan sumber daya yang terdapat di wilayah tersebut. Selain informasi mengenai latar belakang konflik, informasi mengenai kapasitas ekonomi, industri, dan penguasaan teknologi para pihak juga penting untuk diperhatikan. Ketika para pihak saling memahami kepentingan, tujuan dan kapasitas satu sama lain, kompromi akan mudah tercapai.

Dalam kasus North Sea Continental Shelf Case misalnya antara Jerman dan Denmark. Jerman memahami bahwa Denmark sebagai pemilik area pantai berbentuk menjorok atau cembung ke arah Laut Utara memiliki hak bagian ZEE lebih banyak atau luas daripada Jerman yang memiliki bentuk pantai cekung pada Laut Utara, atas dasar prinsip equidistant. hukum internasional. Hal ini menimbulkan Denmark berhak dalam mengklaim ZEE lebih luas daripada Jerman di laut utara hingga bersinggungan dengan wilayah ZEE Jerman. Di sisi lain Jerman kemudian berdalih di hadapan ICJ bahwa Jerman meminta ICJ untuk menilai pembagian proporsi zona landas kontinen yang juga merupakan bagian dari ZEE kedua belah pihak menjadi wilayah pengelolaan Bersama atau equitable share dan tidak berdasar pada prinsip equidistance (Guernsey, 2000). Dalam hal ini Jerman menyadari bahwa Denmark memiliki kepentingan untuk menjaga cadangan sumber daya alam minyaknya namun tidak memiliki keperluan lebih untuk mengeksplorasinya, sedangkan Jerman memiliki kebutuhan dan teknologi untuk mengeksplorasinya namun tidak memiliki wilayah cadangan minyak tersebut.

Hal yang sama kemudian juga disadari oleh Hakim Phillip C. Jessup, yang menyadari bahwa tujuan utama negaranegara yang berkonflik ekonomis memanfaatkan sekaligus memiliki cadangan hidrokarbon di dasar laut tersebut. 
Kebijakan agresif pemerintah China dalam berupaya mengakuisisi Laut Natuna sebagai bagian dari wilayah perairan historis mereka. Menuai protes keras dari Indonesia, China secara bersikukuh melakukan klaim sepuluh garis putus-putus (Ten Dash Line) berdasarkan alasan perairan historis, walaupun tanpa ada landasan hukum internasional yang jelas dan terbukti telah melanggar United Nations Convention on The Law of The Sea 1982 (UNCLOS 1982) yang telah diratifikasi oleh China sendiri. China dengan show of force kekuatan militernya tetap bertahan dengan klaim tersebut.

Sedangkan Indonesia di sisi lain telah memiliki kepulauan Natuna beserta perairan di sekitarnya yaitu Laut Natuna sejak daerah kepulauan Riau termasuk Natuna, telah menyerahkan diri ke dalam Wilayah Republik Indonesia di bawah Provinsi Kalimantan Tengah pada 18 Mei 1956. Hingga tahun 2019, Batasan wilayah landas kontinen dan zona ekonomi eksklusif Kepulauan dan Laut Natuna telah disepakati dan diakui antara Indonesia dan Malaysia di tahun 1969, melalui continental shelf boundaries agreement 1969 yang menyatakan mengenai batas delimitasi landas kontinen Indonesia di bagian timur dan barat Laut Natuna. Sedangkan untuk mengatur delimitasi wilayah bagian utara Laut Natuna Indonesia dan Vietnam telah menandatangani Indonesia-Vietnam Continental Shelf Boundaries Agreement pada Tahun 2003 yang menyimpulkan kesepakatan delimitasi landas batas kontinen yang diakui oleh Indonesia dan Vietnam.

Indonesia sebagai negara yang telah meratifikasi UNCLOS 1982 tunduk secara penuh terhadap ketentuan pembagian wilayah zona perairan Zona Ekonomi Eksklusif (ZEE) berdasarkan bagian ke 5 artikel 55 hingga artikel 75, serta ketentuan zona landas kontinen yang diatur pada bagian ke-6 artikel 76 hingga 85 UNCLOS 1982. Dengan ini Indonesia secara sah telah menjalankan kewajiban berdasarkan UNCLOS 1982. Dengan demikian Indonesia berhak untuk melakukan eksplorasi dan eksploitasi sumber daya alam yang tersimpan di dalam dasar laut (seabed) selama dasar laut tersebut berada di wilayah ZEE dan landas kontinen Indonesia, dengan memperhatikan faktor kelestarian lingkungan dan keselamatan navigasi internasional.

Motif dan kepentingan utama China dalam penguasaan wilayah Laut Natuna Utara adalah selain mendapatkan sumber tangkapan ikan bagi nelayan-nelayan namun juga untuk merebut area cadangan hidrokarbon berupa minyak dan gas alam. Karena bermotif ekonomi, maka sengketa tersebut dianggap akan lebih baik jika dapat diselesaikan melalui jalur diplomasi dan negosiasi ekonomi, sehingga tercipta suatu win-win solution bagi Indonesia maupun China. Salah satu cara untuk menjamin keuntungan kedua belah pihak adalah melalui penjajakan kerjasama Joint Development Agreement.

\section{Pengakuan terhadap Sengketa}

Faktor lainnya dalam menentukan keberhasilan suatu Joint Development Agreement adalah melalui adanya pengakuan para pihak mengenai kondisi sengketa klaim wilayah yang saling tumpang tindih antar negara. Pengakuan menjadi faktor penting karena merupakan objek yang mendasari terbentuknya Joint Development Agreement itu sendiri. Tanpa adanya pengakuan para pihak mengenai sengketa yang terjadi, akan menempatkan Joint Development Agreement tersebut menjadi status quo.

Langkah-langkah yang dapat ditempuh suatu negara dalam mendorong pengakuan terhadap keadaan sengketa itu sendiri wajib dimulai dari pemahaman bahwa penerapan mekanisme Joint Development Agreement merupakan suatu alternatif penyelesaian sengketa yang dapat menguntungkan para pihak. Setelah para pihak memahami dengan benar tujuan dari disepakatinya Joint Development Agreement, kedua para pihak yang terlibat tidak hanya harus melakukan kompromi terhadap tuntutan kepentingannya masing-masing. Namun juga perlu untuk 
saling mengakui keberadaan political will serta posisi para pihak dalam sengketa. Hal yang terjadi di Laut Natuna adalah, karena klaim pemerintah China mengenai nine dash line tidak memiliki dasar hukum internasional. Maka cukup sulit bagi negara lain termasuk Indonesia untuk kemudian mengakui posisi klaim China berdasarkan suatu norma hukum.

Hingga saat ini klaim nine dash line China sama sekali tidak dianggap oleh Indonesia, dan sebaliknya Indonesia secara de jure memiliki yurisdiksi berupa ZEE pada wilayah Laut Natuna bagian utara tersebut Maka dari itu secara otomatis Indonesia tidak akan pernah secara hukum atau de jure mengakui keberadaan sengketa dengan China pada Laut Natuna bagian utara, walaupun secara de facto Indonesia menyadari bahwa peningkatan aktivitas armada perikanan dan militer China di Laut China Selatan merupakan implikasi dari klaim negara tirai bambu tersebut. Dalam kondisi ini maka akan sulit untuk memulai diskusi formal maupun diplomasi untuk membahas mengenai posisi sengketa antar kedua belah pihak. Jika Indonesia ingin membuka pembicaraan mengenai JDA dengan pemerintah China, maka secara tidak langsung Indonesia akan mengakui keberadaan dari klaim nine dash line pemerintah China. Dimana hal ini sulit dan hampir tidak mungkin untuk terjadi.

\section{Stigma Politik dan Sosial}

Faktor yang tidak kalah penting menjadi faktor yang harus diperhatikan oleh Indonesia adalah faktor stigma politik dan sosial masyarakat Indonesia. Walaupun secara ekonomi China turut berperan dalam membangun perekonomian Indonesia, stigma anti China dan anti komunis yang tumbuh dan melekat sejak akhir orde lama, masih dapat dirasakan. Timbulnya beberapa penolakan dan kritik dari masyarakat terhadap kebijakan pemerintah yang condong kepada pemerintah China sebagai mitra pembangunan di Indonesia, terlepas dari prinsip non blok yang digunakan pemerintah Indonesia dalam hubungan Internasional. Stigma negatif terhadap China tersebut tetap berada di tengah-tengah masyarakat.

Faktor stigma politik dan sosial dinilai berpotensi sangat mempengaruhi kestabilan berjalannya Joint Development Agreement. Stigma politik dan sosial mempengaruhi pandangan umum berupa masyarakat, pengusaha hingga individu yang turut terlibat sebagai subjek yang menjalankan Joint Development Agreement di garis depan. Jika kesepakatan negara tersebut tidak didukung dengan kemauan willingness pelaku dan stakeholder, maka joint development agreement tersebut akan bersifat vakum. Stigma politik dan sosial menjadi faktor yang cukup berperan dalam tatanan ekonomi pasar bebas, ketika proses ekonomi dipengaruhi oleh stigma masyarakat.

Stigma sosial dan politik merupakan faktor yang cukup sulit untuk dieliminasi, pasalnya faktor ini bersifat mengakar ke dalam nilai-nilai bernegara dan bermasyarakat suatu bangsa. Adapun cara yang dapat ditempuh guna melaksanakan suatu JDA dengan China ataupun negara lain yang diwarnai stigma sosial dan politik negatif upaya dalam meluruskan stigma politik dan sosial dapat dilakukan melalui kampanye positif mengenai win-win solution yang dapat dicapai dengan pemerintah China melalui pembuatan JDA dalam pemanfaatan hidrokarbon.

\section{Faktor Lain-Lain}

Faktor lain-lain berupa faktor kapasitas ekonomi turut berperan dalam menentukan tercapainya equitable share dan equitable result dalam pelaksanaan JDA. Adanya studi dan pemahaman mengenai kapasitas ekonomi yang dimiliki kedua belah pihak, kemudian dapat menentukan hak dan kewajiban masing-masing pihak dalam pelaksanaan JDA. Termasuk menentukan pihak mana yang menyediakan lahan, finansial, serta sumber daya manusia yang diperlukan dalam pelaksanaan JDA. Perumusan hak dan kewajiban serta para 
pihak secara fair and equitable menjadi kunci dalam kesuksesan berjalannya suatu JDA.

Secara ekonomi Indonesia dan China memiliki hubungan ekonomi yang begitu erat melalui ketergantungan perdagangan. Beberapa produk ekspor Indonesia berupa komoditas bahan makanan dan minyak sawit sebagian besar dibeli oleh China, sebaliknya alat-alat kebutuhan rumah tangga dan beberapa kebutuhan pokok Indonesia mengimpor dari China. Menurut hasil kajian Badan Pengkajian dan Pengembangan Perdagangan Kementerian Perdagangan, setiap 1 persen depresiasi pertumbuhan ekonomi China akan berdampak pada perlambatan ekonomi Indonesia kurang lebih sebesar $0.23 \%$. Dalam skala ini dapat dinyatakan bahwa secara ekonomi Indonesia cukup bergantung kepada keberadaan China. Maka dalam pembuatan JDA dengan China, Indonesia perlu memperhatikan dan memperhitungkan kompensasi ketergantungan ekonomi tersebut, jangan sampai dengan adanya JDA dalam hal eksplorasi dan eksploitasi sumber hidrokarbon justru kemudian memperbesar rasio ketergantungan ekonomi Indonesia kepada China, yang akan melemahkan posisi tawar Indonesia terhadap China.

\section{Simpulan dan Saran}

Dari uraian-uraian tersebut, maka dapat disimpulkan bahwa dalam menjawab hal-hal apa sajakah yang perlu diperhatikan Indonesia dalam mempersiapkan dan membuat Joint Development Agreement dengan China dalam rangka pemanfaatan bersama sumber daya alam hidrokarbon di wilayah sengketa? Pembahasan mengenai bagaimana suatu negara seharusnya merancang atau mempersiapkan suatu JDA merupakan sebuah topik bahasan yang luas. Dalam hal ini tidak ada suatu standar baku atau acuan norma yang dapat digunakan untuk mengukur syarat-syarat JDA secara hukum. Melainkan tiap-tiap pihak bebas menentukan hukum yang berlaku bagi dirinya sendiri. Hingga poin ini maka perlu dilakukan kajian mengenai aspek atau faktor apa saja yang kemudian harus diperhatikan oleh para pihak, karena faktor tersebut memiliki peluang akan menentukan atau justru berupaya menghambat keefektifan JDA.

Pertama Indonesia perlu mempersiapkan penyelarasan political will dengan China melalui jalur negosiasi diplomatik mengenai sengketa yang timbul di wilayah Laut Natuna bagian utara. Kedua penyelarasan political will melalui pengutaraan kepentingan dan maksud harapan negara kepada pihak China secara tidak langsung memiliki arti bahwa Indonesia kemudian mengakui adanya hak klaim China secara hukum pada wilayah perairan tersebut. Hal ini dapat menjadi hambatan besar bagi upaya memulai JDA baik dari sisi Indonesia maupun China. Kedua, pada kondisi dimana pembahasan mengenai JDA sudah terinisiasi antara pemerintah China dan Indonesia, hal-hal yang perlu diperhatikan oleh Indonesia adalah memperhatikan serta mempertimbangkan aspek stigma sosial dan politik serta adanya unsur ketergantungan ekonomi yang cukup besar bagi Indonesia kepada China yang perlu dikompensasi agar tidak mempengaruhi berjalannya JDA secara fair and equitable (adil dan seimbang). Menurut William Stormont dan Ian Townsend-Gault, faktor political will merupakan waktor terpenting dalam menjamin keberlanjutan dan keberhasilan berjalannya JDA.

Dalam kasus Indonesia-China political will kedua negara tersebut dapat dijalankan dengan kunci meruntuhkan stigma sosial dan politik pemerintah Indonesia dan China, serta berupaya sedikit memberikan ruang bagi kerjasama eksplorasi dan eksploitasi bersama dengan China. Terakhir perlu disadari bersama bahwa JDA dalam penyelesaian permasalahan pemanfaatan sumber daya hidrokarbon di suatu wilayah sengketa, hanya berperan sebagai solusi yang menjembatani tujuan dan kepentingan kedua belah pihak dalam mengeksplorasi dan mengeksploitasi sumber daya alam, dan bukan menjadi suatu solusi 
permanen dalam penyelesaian sengketa. Dengan adanya JDA tidak berarti status quo wilayah yang dipersengketakan tersebut terpecahkan. Melainkan tetap ada namun JDA dalam hal ini berfungsi untuk membantu mencapai tujuan bersama tanpa menunggu penyelesaian terhadap sengketa yang terjadi.

JDA hanya berperan sebagai jembatan alternatif bagi pemanfaatan sumber daya alam di wilayah sengketa yang dalam keadaan deadlock. Junaidu Bello Marshall dalam artikelnya berpendapat bahwa kekuatan JDA dalam penyelesaian sengketa terletak pada kemampuan JDA dalam meningkatkan kualitas hubungan bilateral atau multilateral antar negara (Marshall, 2014). Penguatan tersebut diprakarsai oleh terjalinnya kerjasama yang erat antar negara dalam mengelola secara bersama dan mencapai tujuan bersama yang dituangkan dalam JDA. Oleh karena itu melalui JDA diharapkan para pihak yang bersengketa kemudian dapat menemukan kesepakatan bersama yang akan menjadi titik terang percepatan penyelesaian status quo wilayah yang disengketakan. Walaupun ide dan konsep tersebut terdengar utopis dan tidak mudah untuk dilaksanakan di dunia nyata.

\section{DAFTAR PUSTAKA}

Alexander, L. M., \& Charney, J. I. (2014). Dubai-Sharjah (1981) [Report Number 7-4 (Add. 1)]. In International Maritime Boundaries Online. http://doi.org/10.1163/imbo-book-7_7

Anderson, D. H. (2015). United Nations Convention on the Law of the Sea maritime boundary delimitation methodology - territorial sea - exclusive economic zone - continental shelf beyond 200 nautical miles . American Journal of International Law. Washington : Cambridge University Press .

Azaria, D. (2016). The Scope and Content of Sovereign Rights in Relation to NonLiving Resources in the Continental
Shelf and the Exclusive Economic Zone - The Journal of Territorial and Maritime Studies . Seoul : McFarland \& Company .

Beckman, R. C., \& Schofield, C. H. (2014). Defining eez Claims from Islands: A Potential South China Sea Change. The International Journal of Marine and Coastal Law. The Netherlands : Brill| Nijhoff http://doi.org/10.1163/1571808512341321

Desbarats, R., Todesco, J., \& Royer, K. (2016). Sole Risk Provisions in Joint Operating Agreements for Unconventional Oil and Gas Development . Alberta Law Review. Alberta Law Review. http://doi.org/10.29173/alr472

Guernsey, K. N. (2000). The North Sea Continental Shelf cases . Ohio Northern University Law Review. Ohio Northern University Law Review .

International Court of Justice. North Sea Continental Shelf Cases Judgement 1969 (1969).

Jain, A. G. (2015). International Court of Justice - maritime territorial dispute boundary delimitation - tacit agreement - equidistance line - equitable apportionment . American Journal of International Law . Cambridge University Press .

Lucky, A. (2015). The Issues Concerning the Continental Shelf: Reflections . International Community Law Review . The Netherlands : Brill | Nijhoff . http://doi.org/10.1163/1871973212341296

Masahiro Miyoshi. (1999). The Joint Development of Offshore Oil and Gas in Relation to Maritime Boundary Delimitation. Maritime Briefing, 2(52).

MORTON, K. (2016). China's ambition in the South China Sea: is a legitimate maritime order possible? . International 
Affairs . Wiley Subscription Services, Inc . http://doi.org/10.1111/14682346.12658

Ong, D. M. (1999). Joint Development of Common Offshore Oil and Gas Deposits: "Mere" State Practice or Customary International Law? The American Journal of International Law. http://doi.org/10.2307/2555344

Ong, D. M. (1999). The 1979 and 1990 Malaysia-Thailand Joint Development Agreements: A Model for International Legal Co-operation in Common Offshore Petroleum Deposits? . The International Journal of Marine and Coastal Law . Aspen Publishers, Inc . http://doi.org/10.1163/15718089920492 384

Onorato, W. T. (1981). Joint development of seabed hydrocarbon resources: an overview of precedents in the North Sea. Energy.

http://doi.org/10.1016/03605442(81)90041-4

Peoples, L. (2010). Legal Research Methods in a Modern World: A Coursebook, Third Edition. By J. Paul Lomio, Henrik S. Spang-Hanssen, and George D. Wilson. Copenhagen, Denmark: DJØF Publishing, 2011. Pp 480. ISBN 97887-574-2467-6. US\$55 . International Journal of Legal Information . http://doi.org/10.1017/S0731126500005 953
Sforza, J. M. (1999). The Timor Gap dispute: the validity of the Timor Gap Treaty, self-determination and decolonization . Suffolk Transnational Law Review. Suffolk University Law School .

Supriyanto, R. A. (2016). Out of Its Comfort Zone: Indonesia and the South China Sea . Asia Policy. Seattle : THE NATIONAL BUREAU of ASIAN RESEARCH .

United Nations General Assembly. (1994). Convention on the Law of the Sea. The International Journal of Marine and Coastal

Law. http://doi.org/10.1163/15718089720491 594

Wang, K.-H. (2010). The ROC's Maritime Claims and Practices with Special Reference to the South China Sea . Ocean Development \& International Law: Issues in the South China Sea . Taylor \& Francis Group . http://doi.org/10.1080/00908320.2010.4 99282

XUE, S., \& Assistant Professor in the Institute of International Studies Shanghai, F. U. (n.d.). Why Joint Development Agreements Fail: Implications for the South China Sea Dispute . Contemporary Southeast Asia - Singapore : ISEAS - Yusof Ishak Institute . http://doi.org/10.1355/cs41$3 d$ 